Reviewed Article: Clinic, the University and Society

\title{
SITUATING SOCIAL PROBLEMS IN THE CONTEXT OF LAW: FOSTERING PUBLIC INTEREST LAWYERS IN HONG KONG
}

\author{
Amy Barrow ${ }^{1}$ \\ The Chinese University of Hong Kong
}

\begin{abstract}
Hong Kong is often perceived as a global financial centre; an international, cosmopolitan city. Though Hong Kong has prospered economically, a myriad of social problems persist which undermine equity and social justice in society and many interest groups lack political and legal representation. Consequentially, the development of public interest law provides a pedagogical opportunity to cultivate individuals with the capacity to critically engage with and respond to social problems in society. While clinical legal education programmes provide one avenue of fostering public interest lawyers, socio-legal courses also provide a valuable means of developing socially responsible lawyers. First examining the context of Hong Kong law, this article considers the development of public interest law in Hong Kong and the role of socio-legal courses in fostering the development of public interest lawyers. Specifically, the article examines The Chinese University of Hong Kong, Faculty of Law's flagship course, 'The Individual, the Community and the Law' to explore how socio-legal courses can foster socially responsible lawyers.
\end{abstract}

\footnotetext{
${ }^{1}$ Amy Barrow is Assistant Professor in the Faculty of Law at The Chinese University of Hong Kong. This article draws on research conducted by Amy Barrow (Principal Investigator) and Joy L. Chia (CoInvestigator) on Fostering Public Interested Lawyers: The Individual, the Community and the Law funded by a Lee Hysan Foundation Research Grant and an Endowment Fund Research Grant awarded by United College, The Chinese University of Hong Kong. The author would like to thank Garf Chan and Esther Erlings for their invaluable research support during the project.
} 


\section{INTRODUCTION}

Many will be familiar with Hong Kong's neon skyline, which firmly asserts its status as a global financial centre, yet masks a society riddled with inequalities and social problems. Hong Kong's economic success belies a significant wealth gap, with more than 1.3 million $^{2}$ Hong Kong residents living below the poverty line as well as a significant number of vulnerable social groups including migrant workers, refugees and asylum seekers. Hong Kong's social problems stem from a number of unique historical and political factors, which have helped to shape Hong Kong's distinct cultural, legal and political identity. Hong Kong was formally handed over from British colonial rule to the People's Republic of China (PRC) on July 1 ${ }^{\text {st }}, 1997$. Founded on the principle of 'one country, two systems,' Hong Kong Special Administrative Region (HKSAR) enjoys a high degree of autonomy. The adoption of Hong Kong's Basic Law, ${ }^{3}$ a quasiconstitutional legal framework provides for the continuation of the common law system

\footnotetext{
${ }^{2}$ This figure is out of a total population of more than 7 million. 19.6 per cent of the population is classified as poor. See 1.3 million Hongkongers live in poverty, government says, but offers no solution http://www.scmp.com/news/hong-kong/article/1319984/hong-kong-draws-poverty-line-13-million-livingbelow-it 29 September 2013 (Last Accessed 16 April 2015).

${ }^{3}$ The Basic Law of the Hong Kong Special Administrative Region of the People's Republic of China (Adopted at the Third Session of the Seventh National People's Congress on 4 April 1990 Promulgated by Order No. 26 of the President of the People's Republic of China on 4 April 1990 Effective as of 1 July 1997). See www.basiclaw.gov.hk
} 
premised upon the rule of law and independence of the judiciary for a period of fifty years until 2047. ${ }^{4}$

While Hong Kong prides itself as a society built upon the rule of law with a strong, independent judiciary, Hong Kong is undermined constitutionally by a lack of separation of powers between the Legislative Council and the Executive branches of government. Further, Hong Kong currently faces a constitutional crisis with tensions over political reforms in the lead up to the 2017 appointment of the Chief Executive. Presently there is no universal suffrage, although Article 45 of the Basic Law ${ }^{5}$ provides that the Chief Executive of Hong Kong should eventually be elected through a process of universal suffrage.

Given Hong Kong's post-colonial legacy and uncertain political and legal future, this article argues that cultivating law students with the ability and willingness to engage with and work towards addressing social problems is essential for strengthening social justice in Hong Kong. Socio-legal studies potentially play an instrumental role in

\footnotetext{
${ }^{4} \mathrm{Ibid}$ at Article 5. There are a number of notable exclusions to HKSAR's autonomy, principally matters of national security, diplomacy and international affairs, which fall under the power of the Central People's Government of the PRC.

${ }^{5}$ Article 45 of the Basic Law specifies that The Chief Executive of the Hong Kong Special Administrative Region shall be selected by election or through consultations held locally and be appointed by the Central People's Government. The method for selecting the Chief Executive shall be specified in the light of the actual situation in the Hong Kong Special Administrative Region and in accordance with the principle of gradual and orderly progress. The ultimate aim is the selection of the Chief Executive by universal suffrage upon nomination by a broadly representative nominating committee in accordance with democratic procedures. The specific method for selecting the Chief Executive is prescribed in Annex I: "Method for the Selection of the Chief Executive of the Hong Kong Special Administrative Region".
} 
fostering public interest lawyers, with the capacity to identify social problems, ensuing legal needs and underrepresented litigants. First, this article will consider the political situation in Hong Kong as well as cultural and social factors, which shape the 'context of law.' Second, the article will explore public interest law's potential in Hong Kong including the current use of strategic litigation. While individuals have increasingly turned to the process of judicial review as a mechanism of redress in the face of Hong Kong's democratic deficit, the article will argue that there is scope to strengthen public interest law by fostering socially responsible lawyers with the capacity to identify social problems and unmet legal needs. The article will finally turn to consider the role of socio-legal education in fostering public interest lawyers in Hong Kong, by critically examining the flagship course, The Individual, the Community and the Law (ICL), at the Faculty of Law, the Chinese University of Hong Kong (CUHK). Though this paper focuses specifically on the Hong Kong context, the author hopes to add to comparative pedagogical discourses on how socio-legal studies can be effectively integrated into law curriculums in different jurisdictions to foster socially responsible lawyers with an awareness of the intersections between law and society. 


\section{THE ‘CONTEXT OF HONG KONG LAW’}

A number of unique historical and political factors have shaped the context of law in Hong Kong and continue to have implications for the rule of law and civil liberties. Hong Kong was under British Colonial rule for a period of 150 years. ${ }^{6}$ In the early eighties, with the lease of the New Territories due to expire in 1997, Hong Kong's sovereignty was again called into question. Negotiations between Deng Xiaoping and Margaret Thatcher led to the signing of the Sino-British Joint Declaration ${ }^{7}$ in 1984, which provided for the resumption of Chinese sovereignty over Hong Kong. The Declaration stipulated that the socialist system of the People's Republic of China (PRC) would not be practiced in Hong Kong for a period of fifty years and this principle is clearly articulated in Hong Kong's Basic Law. ${ }^{8}$ Only a few years after the signing of the

Sino-British Joint Declaration and prior to the handover, the Tiananmen Square

${ }^{6}$ Following the defeat of China's Qing Dynasty government in the First Opium War of 1842, Hong Kong Island was ceded to the British, followed shortly after by Kowloon. The New Territories was leased to the British for a period of 99 years from 1898 to 1997. British Colonial rule was briefly interrupted during the Japanese occupation of 1941-1945. Under British rule Hong Kong evolved into a centre for international trade. The population of Hong Kong rapidly expanded, with the arrival of large numbers of refugees from China in the early $20^{\text {th }}$ century, particularly during the Cultural Revolution in China. Though Hong Kong flourished economically, the British Colonial Government faced considerable dissent from Chinese Nationalists as well as other opposition groups. In 1967, for example, Hong Kong experienced a series of riots triggered by labour disputes. Leftist sympathisers rioted against the then Colonial Government. According to official statistics 51 persons were killed and 832 people were injured. By the end of 1967, 1,936 people had been convicted for their participation in the riots. 2012 marked the $45^{\text {th }}$ anniversary of the '67 riots. See Old leftists pay respects to workers killed in '67 riots South China Morning Post, 7 May 2012. ${ }^{7}$ Joint Declaration of the Government of the United Kingdom and Northern Ireland and the Government of the People's Republic of China, Cap. 2301, 19 December 1984.

${ }^{8}$ Hong Kong Basic Law Article 5 states that 'The socialist system and policies shall not be practised in the Hong Kong Special Administrative Region, and the previous capitalist system and way of life shall remain unchanged for 50 years.' 
massacre on June 41989 caused grave political concern of the potential consequences of Chinese rule on the territory, particularly that the rule of law and civil liberties may erode. ${ }^{9}$

Significantly, a number of international human rights instruments were extended to Hong Kong by the British Colonial Government ${ }^{10}$ prior to the handover, including the International Covenant on Civil and Political Rights (ICCPR) ${ }^{11}$ as well as the International Covenant on Economic, Social and Cultural Rights (ICESCR). ${ }^{12}$ Article 39 of the Basic Law acknowledges that the ICCPR remains in force and shall be implemented through Hong Kong laws. The ICCPR has been formally incorporated into Hong Kong law through the Hong Kong Bill of Rights Ordinance (BORO) including the principle of non-discrimination. ${ }^{13} \mathrm{~A}$ number of laws also aim to protect distinct groups within society that have traditionally been disadvantaged, marginalized or underrepresented within society such as women and ethnic minority groups.

Following the adoption of the Beijing Declaration and Platform for Action (BPFA) ${ }^{14}$ in 1995 at the international level, the British Government also extended the Convention on the Elimination of All Forms of Discrimination against Women (CEDAW) to Hong

\footnotetext{
${ }_{9}^{9}$ Chen, Albert H.Y. "The Rule of Law under 'One Country, Two Systems': The Case of Hong Kong 19972010" (2011) 6:1 National Taiwan University Law Review 269-299.

${ }^{10}$ The British Colonial Government failed to extend human rights protections to Hong Kong at an earlier stage, even though some treaty provisions were already applicable in the UK context.

${ }^{11}$ International Covenant on Civil and Political Rights, 16 December 1966, 999 UNTS 171.

12 International Covenant on Economic, Social and Cultural Rights, 16 December 1966, 993 UNTS 3.

${ }^{13}$ Hong Kong Bill of Rights Ordinance (BORO) Cap. 383, 1991, Article 1.

${ }^{14}$ Beijing Declaration and Platform for Action (BPFA).
} 
Kong in 1996. Further, a series of piecemeal anti-discrimination legislation provide protection on the grounds of sex, disability, family status and race, specifically the Sex Discrimination Ordinance (SDO) ${ }^{15}$ and Disability Discrimination Ordinance (DDO) ${ }^{16}$ adopted in 1995, the Family Status Discrimination Ordinance (FSDO) ${ }^{17}$ adopted in 1997 and latterly the Race Discrimination Ordinance (RDO) adopted in 2008. ${ }^{18}$

On paper, Hong Kong appears to have a strong rights-based legal framework ${ }^{19}$ providing for the protection of individuals and distinct interest groups within society, thus creating an enabling environment for cause lawyering particularly around civil and political rights. ${ }^{20}$ However, there are noticeable absences in legal protection, which leave minority groups susceptible to discrimination. Specifically, there is no antidiscrimination legislation on the basis of sexual orientation and gender identity. In the absence of statutory protections, individuals have increasingly sought legal redress through judicial review to challenge the constitutionality of legislation.

\footnotetext{
${ }^{15}$ Sex Discrimination Ordinance (SDO) Cap. 480, 1995.

${ }^{16}$ Disability Discrimination Ordinance (DDO) Cap. 487, 1995.

${ }^{17}$ Family Status Discrimination Ordinance (FSDO) Cap. 527, 1997.

${ }^{18}$ Race Discrimination Ordinance (RDO) Cap. 602, 2008.

${ }^{19}$ Additionally, a number of institutional mechanisms potentially help to support the advancement of equal opportunities, principally, the Equal Opportunities Commission (EOC), a statutory body charged with advancing equality and eliminating discrimination. The EOC has no powers of adjudication and its role is limited to those powers and functions prescribed by s. 64 of the SDO S. 64 of the Sex Discrimination Ordinance 1(d) for example states that where any unlawful action under the Ordinance has been determined, the Commission should effect a settlement of the matter by conciliation. ${ }^{20}$ Tam, Waikeng 'Political Transition and the Rise of Cause Lawyering: The Case of Hong Kong' Law \& Social Inquiry Vol. 35, Issue 3 at 671.
} 
STRATEGIC LITIGATION AS A MEANS TO SECURE LEGAL PROTECTIONS AND

\section{ITS LIMITATIONS}

Significantly, the use of strategic litigation in the form of judicial review has been adopted to secure rights, while simultaneously being used as a tool to foster public education and awareness of minority rights. To illustrate, the development of legal protections for LGBTI individuals has been piecemeal and largely as a result of judicial review cases launched to challenge existing laws which contravene Hong Kong's Basic Law. For example, the landmark 2006 case of William TC Roy Leung ${ }^{21}$ successfully challenged a number of provisions under the Hong Kong Crimes Ordinance ${ }^{22}$ for violating privacy and equality protections situated within Hong Kong's Basic Law (Articles 25 and 29) and BORO (Articles 1, 14 and 22) including s. 118 (C) of the Crimes Ordinance, which set the age of consent for buggery between same-sex couples at 21 years of age, with punishment of life imprisonment for offenders. Conversely, the age of consent for vaginal intercourse was set at 16 and punishment limited to five years.

In evaluating the inconsistency in age of consent between same-sex and opposite-sex couples, Judge Geoffrey Ma stated that “[d]enying persons of a minority class the right

\footnotetext{
${ }^{21}$ William TC Roy Leung v Secretary for Justice [2006] 4 HKLRD 211 (CA).

${ }_{22}$ Crimes Ordinance Cap. 200, 1972. The applicant specifically challenged provisions under s.118C, H and J, which were added to the Crimes Ordinance in 1991.
} 
to sexual expression in the only way available to them, ${ }^{23}$ even if that way is denied to all, remains discriminatory when persons of a majority class are permitted the right to sexual expression in a way natural to them." ${ }^{24}$ Though the Court declared relevant sections of the Crimes Ordinance unconstitutional, the ordinance was only recently amended to reflect the Court's ruling in December 2014. The time lag between the ruling and the Legislative Council's amendment of legislation is thus severely protracted and points to the limitations of using judicial review as a form of strategic litigation to secure minority rights.

On the one hand, a surge of judicial review cases suggests that there is broad recognition of the independence and impartiality of the Hong Kong judiciary as well as the rule of law in society. ${ }^{25}$ On the other hand, the use of the Courts as an avenue to seek redress could also be due to Hong Kong's perceived democratic deficit as a result of its Executive-led Government structure, which potentially undermines equity and social justice. Significantly, the Legislative Council is made up of both geographical ${ }^{26}$

\footnotetext{
${ }^{23}$ Holning Lau, who has significant expertise on gender, sexuality and the law in Hong Kong suggests that there are limitations in the Court of Final Appeal's reasoning, which focused on penetrative sex thus oversimplifying expressions of human sexuality between same-sex couples. See Lau, Holning 'Sexual Orientation and Gender Identity: American Law in Light of East Asian Developments' Harvard Journal of Law E Gender 31, 67, 2008 at p.85.

${ }^{24}$ Leung TC William Roy v Secretary for Justice [2006] 4 HKLRD 211 (CA), at para. 48.

${ }^{25}$ Kong, Karen 'Public Interest Litigation in Hong Kong' Civil Justice Quarterly Vol. 28, Issue 3 (2009) at 331.

26 There are five geographical constituencies in Hong Kong, Hong Kong Island, Kowloon West, Kowloon East, New Territories West and New Territories East.
} 
and functional constituencies. ${ }^{27}$ Functional Constituencies represent professional groups within society such as the Legal Sector, Education Sector and other interest groups, for example the Heung Yee Kuk, which represents rural indigenous interests within the New Territories. While geographical constituencies are voted in by a process of direct election, Functional constituencies are voted in by a select group of eligible voters. This leaves noticeable absences in legal and political representation, particularly for groups within society such as women who stay at home or work in the informal sector, as well as other individuals who do not belong to a recognized profession and other minority groups.

Further, the political polarization of pan-democrats and pro-establishment lawmakers potentially risks undermining the due process of lawmaking leading to substantial delays in law reform. In 2014 for example, the Marriage (Amendment) Bill, ${ }^{28}$ which sought to provide post-operative transgender individuals with the right to marry following the landmark case of $\mathrm{W} v$ Registrar of Marriages, ${ }^{29}$ was vetoed in the

\footnotetext{
27 The Basic Law of the Hong Kong Special Administrative Region Annex II.

${ }^{28}$ The Marriage (Amendment) Bill was triggered by the case of $\mathrm{W}$, a post-operative transgender woman, who challenged the constitutionality of the Marriage Ordinance Cap. 181, s.40 and the Matrimonial Clauses Ordinance, which in effect impaired her right to marry under Article 37 of the Basic Law and Article 19(2) of the Bill of Rights Ordinance. The Marriage Ordinance replicates the English case, Hyde v Hyde's definition of marriage (Hyde v. Hyde and Woodmansee [LR] 1 P\&D 130), that is the heteronormative union of one man and one woman to the exclusion of all others. The Court of Final Appeal reasoned that the denial of W's right to marry her male partner, effectively denied her right to marry at all and was therefore unconstitutional.

${ }^{29}$ W v Registrar of Marriages [2013] HKCFA 39.
} 
Legislative Council by both pan-democrat and pro-establishment lawmakers. ${ }^{30}$ Proestablishment lawmakers suggested that the parameters of marriage should not be extended without wider public consultation while pan-democrats objected to the requirement that transgender individuals should gave to go through full sex reassignment surgery before being recognized in their acquired gender.

Significantly, these and many other landmark cases in Hong Kong result from strategic litigation challenges, which go to the heart of the Basic Law. While constitutionally significant, pedagogically these cases also offer important illustrations of strategic litigations' promise as well as limitations, and thus form the bedrock of clinical legal education and other experiential learning courses including mooting. Though cause lawyering and the use of strategic litigation have been able to achieve considerable successes over the years, pedagogically it is also important to look beyond case law alone to wider claim-making in society and the framing of social problems, which may offer an alternative means of identifying unmet legal needs.

\footnotetext{
${ }^{30}$ See Transgender Marriage Law Vetoed by Legco http://www.scmp.com/news/hongkong/article/1622339/legco-vetoes-transgender-marriage-law-minister-accused-not-lobbying, 23 October 2014. (Last Accessed 17 April 2015).
} 


\section{CLAIMS-MAKING: FRAMING SOCIAL PROBLEMS IN THE CONTEXT OF HONG}

\section{KONG LAW}

Merton explains social problems as physical or mental damage caused to individuals in society which may offend the values or standards of a large segment of society. ${ }^{31}$ Spector and Kitsuse theorise social problems as a process of claims-making. ${ }^{32}$ First, private problems have to be transformed into public issues, a process which is very much dependent on the power of claims-making by different groups and whether it is feasible to secure wider support from the public. During this process, resistance towards opposing claims may help to secure the objective of bringing the issue into the public domain, or if claims-making is ineffective, issues may shrink back into the private domain. Interest groups may adopt a range of strategies in a bid to secure formal recognition, ${ }^{33}$ whether through public demonstrations, petition campaigns or through mass media campaigns. There is a risk however, that governments may effectively try to bury the issue at this stage. At the third stage, the absence of or inadequacy of solutions generated to address the issue further problematise the issue. Finally, in the absence of an effective institutional response, groups may seek to

\footnotetext{
${ }^{31}$ Merton, Robert K., Social Theory and Social Structure, Free Press, 1968.

${ }^{32}$ Malcolm Spector and John Kitsuse (2001), Constructing Social Problems, Transaction Publishers pp. 143148.

${ }^{33}$ To be established as a social problem, issues need to transcend the private domain and require open acknowledgement in the public domain by policymakers and other stakeholders. Formal recognition of the claims by governments, could for example include establishing a committee to review the issues or claims, may help to cement the issue publically.
} 
develop alternative solutions, which lead to the generation of competing claims that effectively sustain the issue as an ongoing social problem. Equally this process of claims-making is applicable to the Hong Kong context.

In recent years, Hong Kong has witnessed a growing protest culture with regular protests taking place on a range of political, economic, social and cultural issues, which suggest a clear process of claims-making by different interest groups in society. The roots of some of Hong Kong's social problems, many of which are interconnected, in part stem from policies and laws enacted both prior to and following the handover of Hong Kong from the British Colonial Government to the People's Republic of China in 1997. From concerns over pressure placed upon the HKSAR Government to implement Article $23^{34}$ of the Basic Law, which requires the HKSAR Government to enact laws to prohibit any act of treason, secession, sedition or subversion against the Central People's Government, ${ }^{35}$ to contentious proposals on national education reforms, ${ }^{36}$ individuals and groups within society have actively participated in public

\footnotetext{
${ }^{34}$ Article 23 of the Basic Law provides that 'The Hong Kong Special Administrative Region shall enact laws on its own to prohibit any act of treason, secession, sedition, subversion against the Central People's Government, or theft of state secrets, to prohibit foreign political organizations or bodies from conducting political activities in the Region, and to prohibit political organizations or bodies of the Region from establishing ties with foreign political organizations or bodies.'

35 The Article 23 Concern Group was formed in response to the Hong Kong SAR Government's attempt to enact legislation to implement Article 23 in Hong Kong law. Following significant public pressure and mass demonstrations on 1 July 2003, the Bill was shelved indefinitely.

${ }^{36}$ Scholarism is a student activist pro-democracy group, which formed in 2011 in response to concerns over the autonomy of Hong Kong's educational policy. In 2012 the group protested against the proposed adoption of Moral and National Education by the Hong Kong Education Bureau. Controversially, the proposed curriculum appeared to praise communist and nationalist ideology, while being dismissive of democratic governance.
} 
demonstrations. Increasing social and political awareness is evidenced by the growth of civil society organisations campaigning on a range of issues including the status of refugees; working conditions of migrant domestic workers; and the lack of legal protections of vulnerable groups within society including sexual minorities. ${ }^{37}$

The mushrooming of civil society groups, as well as cause lawyering, has firmly entrenched recognition of some of these issues, such as the status of refugees, as social problems. Other issues, for example proposals on National Education, appear more transient in nature but may nevertheless link to the way in which Hong Kong and its citizens' culture and identity are framed and contested, an issue which may itself develop into a social problem. Since the 1997 handover, a significant number of mainland Chinese immigrants have moved to Hong Kong, ${ }^{38}$ while numbers of Mainland Chinese visitors ${ }^{39}$ has also risen, which has resulted in social tensions

${ }^{37}$ Hong Kong has a vibrant and active civil society including community organisations. The last comprehensive overview of Hong Kong's civil society seems to have taken place in 2006. The CIVICUS Civil Society Index (CSI) project was carried out between 2004 and 2005 in Hong Kong. See Civil Society Index Report: Hong Kong Special Administrative Region of China, May 2006 available at Centre for Civil Society and Governance, University of Hong Kong, http://web.hku.hk/ ccsg/CSS.html (Last Accessed 26 March 2015).

${ }^{38}$ Chinese migrants now make up ten per cent of Hong Kong's population. As of March 2013, 760,000 Chinese migrants arrived to permanently settle under the Hong Kong SAR Government's one way permit scheme. See http://www.scmp.com/news/hong-kong/article/1195642/mainland-chinese-migrants1997-now-make-10pc-hong-kong-population 21 March 2013(Last Accessed 31 March 2015).

${ }_{39}$ Tensions have arisen as a result of increased numbers of Chinese tourists to Hong Kong as well as other short term visitors, for example the increasing numbers of Chinese women who come to Hong Kong SAR with the specific intention of giving birth. In January 2013 the Hong Kong SAR Government banned Chinese women from giving birth in public hospitals to try to alleviate the problem. Private hospitals continue to provide maternity and neonatal services to Chinese women. There are a number of pragmatic reasons why Chinese women wish to give birth in Hong Kong, from the implications of China's One Child Policy to desiring better educational opportunities available to children born in Hong Kong. 
between Hong Kong Chinese and Mainland Chinese. ${ }^{40}$ These tensions have been heightened by the recent political crisis, which has drawn attention to the fragility of a political and legal system founded on the principle of "One Country, Two Systems." OCCUPY CENTRAL AND THE UMBRELLA MOVEMENT

Hong Kong currently stands at a political impasse as whether to implement constitutional reforms in line with the Central People's Government's interpretation of 'universal suffrage.' If the Executive fails to implement constitutional reforms accordingly, it must continue with the existing nomination process of HKSAR's Chief Executive by a 1,200-member election committee. In September 2014, ‘Occupy Central,' ${ }^{41}$ a civil disobedience campaign was initiated to challenge the perceived failure of Hong Kong's Executive to implement universal suffrage in accordance with international standards under the International Covenant on Civil and Political Rights (ICCPR). Article 25(b) of the ICCPR specifically states that:

"Every citizen shall have the right and the opportunity (b) to vote and to be elected at genuine periodic elections which shall be by universal and equal suffrage and

\footnotetext{
40 The Equal Opportunities Commission is currently conducting a discrimination law review to evaluate how Hong Kong's existing anti-discrimination ordinances may be improved. One of the central questions has been how to alleviate tensions and practices perceived as discriminatory but not formally recognized as such in law against Chinese immigrants and visitors to Hong Kong SAR. Further details of the Discrimination Law Review can be found at http://www.eocdlr.org.hk/en/index.html (Last Accessed 26 March 2015).

${ }^{41}$ Occupy Central was initiated by Professor Benny Tai, an Associate Professor in the Faculty of Law at The University of Hong Kong together with Associate Professor Kin-Man Chan in the Department of Sociology at The Chinese University of Hong Kong and Reverend Chu Yiu-ming.
} 
shall be held by secret ballot, guaranteeing the free expression of the will of the

electors"

The Central People's Government's current proposal has interpreted this provision to allow for one person, one vote; however Chief Executive Candidates will first be screened and selected by a nominating committee. In effect, Hong Kong residents will have the capacity to elect the Chief Executive from a pool of only two to three candidates. ${ }^{42}$ Significantly, the Umbrella Movement (as it is often referred due to the images of protestors shielding themselves with umbrellas from the Police's pepper spray) lasted for almost three months from 26 September to 15 December 2014. During the protests, the Hong Kong Bar Association condemned the excessive and disproportionate use of force used by the Hong Kong Police. ${ }^{43}$ The Umbrella Movement

${ }^{42}$ According to the Standing Committee of the National People's Congress (NPC) 'The Session is of the view that in accordance with the provisions of Article 45 of the Hong Kong Basic Law, in selecting the Chief Executive of the Hong Kong Special Administrative Region by the method of universal suffrage, a broadly representative nominating committee shall be formed. The nominating committee maybe formed with reference to the current provisions regarding the Election Committee in Annex I to the Hong Kong Basic Law. The nominating committee shall in accordance with democratic procedures nominate a certain number of candidates for the office of the Chief Executive, who is to be elected through universal suffrage by all registered electors of the Hong Kong Special Administrative Region, and to be appointed by the Central People's Government.' For further detail see para. 4, Full text of NPC decision on Hong Kong's Constitutional Development, Office of the Commissioner of the Ministry of Foreign Affairs of the People's Republic of China in the Hong Kong Special Administrative Region http://www.fmcoprc.gov.hk/eng/syzx/tyflsw/t944943.htm (August 31, 2014).

${ }^{43}$ Statement of the Hong Kong Bar Association on the Use of Force by the Hong Kong Police at Harcourt Road on 28 September 2014, Press Release 29 September 2014, available at Hong Kong Bar Association http://www.hkba.org/index.html (Last Accessed 29 January 2014). 
has led to significant scrutiny of the rule of law in Hong Kong and whether it is being eroded along with other civil liberties including freedom of expression. ${ }^{44}$

Given Hong Kong's unique legal and political environment, as well as an absence of adequate statutory protections and legal and political representation for vulnerable groups, there is scope to strengthen public interest law. Pedagogically, while clinical legal education courses offer one means of exposing students to public interest law, socio-legal courses may also potentially foster socially responsible lawyers with heightened sensitivity to social problems that undermine equity and social justice in Hong Kong. In turn, socially responsible lawyers may choose to go on to practice public interest law. The development of socially responsible lawyers may help to strengthen public interest law and facilitate greater public awareness of vulnerable, unrepresented groups in society.

\section{PUBLIC INTEREST LAW AND ITS DEVELOPMENT IN HONG KONG}

Broadly construed, public interest law is employed as a tool used to help marginalized individuals and groups in society though public interest lawyering is undertaken by a wide range of organisations including non-governmental organisations that work to promote and protect human rights or raise awareness of, for example, consumer claims

\footnotetext{
${ }^{44}$ The World Justice Project (WJP) Rule of Law Index ranked Hong Kong 16 out of 99 countries measured. Rule of Law in the World Justice Project: Rule of Law Index http://worldjusticeproject.org/rule-of-lawindex (Last Accessed 20 March 2015).
} 
or environmental issues. ${ }^{45}$ Traditionally, clinical legal education courses have been used as a means to foster public interest lawyers. Specialised legal clinics expose students to experiential learning opportunities which potentially enhance their commitment to public interest and pro bono lawyering. Many law schools in the United States have demonstrated a clear commitment towards promoting student lawyers' participation in public service. ${ }^{46}$ Other jurisdictions including Australia and the United Kingdom, ${ }^{47}$ have adopted clinical legal education programmes. The nature of legal clinics varies substantially. Clinics may be wholly law school funded and housed on campus, ${ }^{48}$ whereas some programmes are offered on an externship basis ${ }^{49}$ and include supervised internships with key partner agencies. ${ }^{50}$

In 1996, the American Bar Association encouraged law schools to provide both voluntary and mandatory legal work opportunities to law students, due to the relatively low number of pro bono lawyers compared with numbers of lawyers in

\footnotetext{
${ }^{45}$ Chaifetz, Jill 'The Value of Public Service: A Model for Instilling a Pro Bono Ethic in Law School.' Stanford Law Review. Vol. 45, No. 6 (Jul., 1993), pp.1695-171 at 1704.

${ }^{46}$ See for example Public Interest Law programmes at Chicago Law School and Columbia Law School.

${ }^{47}$ See for example, Manchester Law School, which set up its first legal advice clinic in 2000 and has subsequently opened a second clinic to cater to the needs of the community in East Manchester http://www.law.manchester.ac.uk/law/legal-advice-centre/ (Last Accessed 26 March 2015).

${ }^{48}$ For example, University of South Australia Legal Advice Clinic.

${ }^{49}$ For example, Griffith University Semester in Practice Program.

${ }^{50}$ See discussion of Australian Clinical Legal Education at Best Practices Australian Clinical Legal Education http:///www.cald.asn.au/assets/lists/Resources/Best Practices Australian Clinical Legal Education Sept 2012.pdf (Last Accessed 26 March 2015).
} 
practice. ${ }^{51}$ Such work may be counted towards the accreditation process upon becoming

a legal practitioner. The American Bar Association encourages legal practitioners to complete at least 50 hours of pro bono work annually. ${ }^{52}$ It is important to recognize that not all pro bono work, that is the provision of free legal advice to unrepresented litigants, would automatically fall within the realm of public interest law, though free legal advice is often facilitated with the aim of benefiting marginalized individuals or vulnerable groups with unmet legal needs. Rhode suggests that the rationale behind fostering pro bono services rests on recognition of access to legal services as a fundamental need, with lawyers bearing some responsibility for ensuring that such legal services are accessible and available. ${ }^{53}$ Further, in a 'democratic social order, equality before the law is central to the rule of law and to the legitimacy of the State.'54

A common objective of promoting law students participation in mandatory ${ }^{55}$ or voluntary pro bono legal programmes is to provide practical legal training ${ }^{56}$ and skills

\footnotetext{
${ }^{51}$ Rhode, Deborah L. Cultures of Commitment: Pro Bono for Lawyers and Law Students, 67 Fordham L. Rev. 2415 (1999) at 2415-2416.

52 See American Bar Association http://www.americanbar.org/groups/legal education/resources/pro bono.html (Last Accessed 17 April 2015).

53 Supra note 50 at 2418.

54 Supra note 50 at 2418.

${ }^{55}$ Some scholars have advocated implementing mandatory pro bono programmes as a method of exposing all students to a broad range of public services. See Rosas, Christina M. (2002) 'Mandatory Pro Bono Publico for Law Students: The Right Place to Start' Hofstra Law Review Vol. 30, Iss. 3 at 1076.

${ }^{56}$ Granfield, in his evaluation of mandatory pro bono programs found that even if participation in mandatory programmes did not lead to a significant increase in pro bono services, such participation nevertheless proved valuable in honing students' professional skills while also providing direct client contact. See Granfield, Robert Institutionalising Public Service in Law School: Results on the Impact of Mandatory Pro Bono Programs 54 Buffalo Law Review 1355, 2006-07 at 1470.
} 
as well as raise awareness of future lawyers' professional duty to help marginalized groups in society to access justice. ${ }^{57}$ Through participation in pro bono programmes, it is anticipated that upon admission to practice, lawyers will be committed to providing pro bono legal services, irrespective of their other professional duties and demands on their time. While there is no such equivalent requirement of pro bono hours stipulated by the Hong Kong Bar Association or Law Society ${ }^{58}$ there is growing recognition of the need to strengthen legal ethics in Hong Kong. Significantly, the Redman-Roper Report on legal education in Hong Kong, which was commissioned by the Advisory Steering Committee of the Review of the Legal Education and Training in Hong Kong in 2000, highlighted the importance of experiential learning opportunities as a means to instill students with a sense of social responsibility. ${ }^{59}$

The Redman-Roper report expressed concern that legal education in Hong Kong adopted a black-letter law approach, with the result that law graduates lacked an expanded view of the world. ${ }^{60}$ Further, the report suggested that narrow, doctrinal approaches to the study of law inhibited the development of law graduates' ability to

\footnotetext{
57 See examples of mandatory pro bono law programmes Lesnick, Howard, 'Why Pro Bono in Law Schools,' 13 Law and Inequality 25 (1994).

58 The Hong Kong Law Society states: 'The Law Society supports and encourages a wide variety of pro bono legal services provided by lawyers to the public of Hong Kong,' but does not stipulate a recommended number of hours service per year. See hklawsoc.org.hk (Last Accessed 17 April 2015).

${ }^{59}$ Redman, Paul and Christopher Roper, Legal Education and Training in Hong Kong, August 2001 at 299.

${ }^{60}$ Ibid at 122.
} 
respond professionally to the needs of ordinary people or those in the 'sandwich class,' that is those in the lower-middle class bracket, whose legal needs were often not met. Significantly, the report suggested that 'law should not be seen as a narrow, selfreferential discipline, but as one intimately connected with other bodies of knowledge and modes of social control and organization.' ${ }^{\prime 1}$ The report's findings are particularly salient given the number of vulnerable groups in Hong Kong including female migrant workers, refugees and those living in poverty, who lack adequate access to justice, a constitutional right guaranteed under Article 35 of the Basic Law. ${ }^{62}$

Awareness of public interest law in Hong Kong, though limited, is developing and there are notable examples of public interest lawyering. During the 1980s, Pamela Baker, a solicitor, pioneered the use of public interest law by bringing a series of landmark cases to challenge Government policies on the treatment of Vietnamese Refugees. ${ }^{63}$ Subsequent strategic litigation cases on minority rights, as discussed above in relation to LGBTI rights, and environmental issues such as the judicial review case of Clean Air Foundation Ltd v The Government of Hong Kong ${ }^{64}$ can also be construed as public

\footnotetext{
${ }^{61} \mathrm{Ibid}$ at 68.

${ }^{62}$ Article 35 of the Basic Law states 'Hong Kong residents shall have the right to confidential legal advice, access to the courts, choice of lawyers for timely protection of their lawful rights and interests or for representation in the courts, and to judicial remedies. Hong Kong residents shall have the right to institute legal proceedings in the courts against the acts of the executive authorities and their personnel.' ${ }^{63}$ See for example R. v Director of Immigration and Refugee Status Review Board ex parte Do Giau \& Others (1992) 1 HKLR 287; Tran Quoc Caong and Khoc The Loc 19912 HKLR 312; Re: Chung Tu Quan \& Ors 19961 HKC 566

${ }^{64}$ Clean Air Foundation, an NGO sought a declaration that the Government had a duty to protect its citizens from the harmful effects of air pollution given the constitutional protection conferred by Article
} 
interest cases. More recently, a network of Public Interested Lawyers, Hong Kong Public

Interest Law Group, ${ }^{65}$ which draws together legal practitioners, academics and students was founded in 2013.

Further, several Faculties of Law in Hong Kong have sought to develop clinical legal education programmes largely in response to the recommendations of the RedmanRoper report, which suggested that clinical legal education should be incorporated at all stages of legal education. ${ }^{66}$ The Law Faculty at The Chinese University of Hong Kong (CUHK), founded ${ }^{67}$ with the vision that all law students should be engaged in the active learning of law in its social context, ${ }^{68}$ developed the Refugee Rights Clinic programme in partnership with the Justice Centre Hong Kong. ${ }^{69}$ This particular clinical legal programme was also developed at the Law Faculty of The University of Hong Kong.

28 of the Basic Law on the right to life and that the Air Pollution Control Ordinance, Cap. 311 and its subsidiary legislation were accordingly inconsistent with Basic Law Article 28. See Clean Air Foundation Ltd v The Government of HKSAR [2007] HKEC 1356.

${ }^{65}$ Hong Kong Public Interest Law Group was co-founded by Azan Marwah, Barrister, Hong Kong and Robert Precht, Founder and President of Justice Labs. Robert Precht's previous positions include federal public defender, assistant dean of public service at the University of Michigan Law School, and China Country Director for PILnet: The Global Network for Public Interest Law.

${ }^{66}$ Supra note 58 at 167.

${ }^{67}$ The Faculty of Law at The Chinese University of Hong Kong is a relatively young institution and the youngest Law Faculty in Hong Kong, having been established in 2008. Its predecessor, the School of Law at The Chinese University of Hong Kong was founded in 2005 and the first cohort of students enrolled in 2006.

68 The Law School at CUHK was founded in 2005 with the vision that all students should acquire the necessary lawyering skills and ethical values to demonstrate leadership and serve the needs of the community. School of Law (CUHK) Mission Statement, submission to the Legislative Council, LC Paper No. CB(2) 1760/05-06(01)

${ }^{69}$ Formerly the Hong Kong Refugee Advice Clinic (HKRAC). 
Additionally, the CUHK's Law Faculty developed a flagship course, The Individual, the Community and the Law, which adopts a 'context of law' approach.

\section{Socio-Legal Studies: An Alternative Means of Fostering Public Interested Lawyers?}

While clinical legal programmes have been adopted by Law Schools with a view to fostering public interested lawyers, it is less clear whether socio-legal courses such as the Individual, the Community and the Law course, have the capacity to foster the same level of engagement with public interest law. First, the doctrinal bias of the undergraduate law curriculum makes the integration of socio-legal studies and empirical research methods particularly challenging. ${ }^{70}$ Second, law schools often exist in a vacuum and there is limited engagement with other disciplines such as the humanities or the social sciences, which means that legal scholars often lack the requisite empirical research and wider interdisciplinary skills required to teach and support student learning of alternative approaches to the study of law.

Further, in the context of Hong Kong's legal education environment, Jones suggests that as a result of globalization and neo-liberalist capitalism, lawyers have been discouraged from critical engagement with the law and this has proved to be the case in Hong Kong, particularly as a result of the socio-political context post- $97,{ }^{71}$ though this may be

\footnotetext{
${ }^{70}$ Caroline Hunter Introduction: Themes, Challenges and Overcoming Barriers in Integrating Socio-Legal Studies into the Curriculum (Ed. Caroline Hunter) Palgrave MacMillan Socio-Legal Studies at 1.

${ }^{71}$ Jones, Carol, 'Legal Education in Hong Kong: Producing the Producers in Steele,' S. \& Taylor, IK. (eds.) Legal Education in Asia. Australia. Routledge.at 108.
} 
changing as the rule of law and other founding principles of the HKSAR come under pressure. ${ }^{72}$ The Law Society professional practice requirements ${ }^{73}$ also leave less room in the curriculum to develop elective courses as compared with other non-vocational degree programmes.

Rather than taking law as the starting point, the Faculty of Law's flagship course, the Individual, the Community and the Law (hereafter ICL) adopts a 'context of law' approach, ${ }^{74}$ which first focuses on the identification of 'social problems' affecting distinct groups in society. This is not to preclude analysis of law and how it relates to social problems. While a 'context of law' approach does consider the role of the law, importantly law is not presented as the primary solution to social problems, which may instead be addressed by other cultural, economic, political or social means. Indeed the law can sometimes exacerbate social problems through inadequately or poorly drafted legislation or through the 'silences' of the law, ${ }^{75}$ which can result in unmet legal needs.

\footnotetext{
${ }^{72}$ According to the Hong Kong's Public Opinion Programme's latest survey results on social indicators released on 4 August 2015, people are less positive about Hong Kong society on issues including compliance with the rule of law and freedom compared with the past ten years http://hkupop.hku.hk/english/ (4 August 2015).

${ }^{73}$ Hong Kong Law Society http://www.hklawsoc.org.hk (Last Accessed 17 April).

${ }^{74}$ Though doctrinal legal studies as a discipline have traditionally been resistant to interdisciplinary research the development of alternative approaches to the study of law including socio-legal studies and Critical Legal Studies have been influential in areas of law, which touch upon social policies and regulation, and increasingly law schools are shifting away from purely doctrinal legal research. See Banakar, Reza and Max Travers 'Law, Sociology and Method' in Theory and Method in Socio-Legal Research Hart Publishing Oxford and Portland Oregon, 2005 at p.9

${ }^{75}$ Hilary Charlesworth referred to the silences of international law in considering the notable absence of gender and women's experiences in the drafting of international legal instruments. See Charlesworth, Hilary 'Feminist Methods in International Law' 93 American Journal of International Law (1999) 379. The
} 
It was envisaged that a 'context of law' approach would steep students with a rich understanding of law's limitations as well as its promise and potentially foster students' awareness of social justice and public interest lawyering. Similar to mandatory pro bono programmes the ICL course is compulsory for all third year undergraduate LLB Law students.

In the longer term, Emeritus Professor Mike McConville, the founding Dean of the Law Faculty at CUHK, conceived that the course may influence students' career aspirations and choices. Though it may take several years for graduating students to reflect on their ICL learning experience, ${ }^{76}$ for some students, the course would heighten their awareness of inequity and social injustice within society and they would thus become socially responsible lawyers. In the longer term, it was envisaged that through students' exposure to social problems, the empirical research and learning opportunities offered by the ICL course would encourage LLB graduates to give something back to the community whether through engagement with public interest law, pro bono or other community service provision.

Without black letter law as the familiar starting point, ICL proves to be somewhat tempestuous. Given that the majority of the compulsory law courses on the LLB programme adopt a doctrinal approach to the study of law and focus on substantive

term is useful more generally to encapsulate the way in which the 'silences' of law more broadly serve to exclude vulnerable groups in society from legal protections.

${ }^{76}$ The ICL course is now in its $6^{\text {th }}$ year of operation on the LLB programme. 
law with little consideration of the cultural, social and political context in which the law is situated, many students feel somewhat uncomfortable to engage with contextual factors as well as social research methods. Starting from the social problem, students are introduced to qualitative and quantitative research methods as well as research ethics before undertaking fieldwork with multiple stakeholders across legal, policy, NGO and other circles. While the course does not include any direct client representation or shadowing of practicing lawyers as such, students do have direct contact with research subjects during empirical research which may involve a process of identifying unmet legal needs.

A principal aim of the ICL course is to encourage students to develop socio-legal research projects for the benefit of selected vulnerable groups within society such as minority groups, migrant workers, ex-offenders and unrepresented litigants. The nature of the ICL course does not lend itself to the traditional lecture-tutorial model, which most doctrinal law courses follow. Pedagogically, the course is delivered through multiple methods including interactive lectures, tailored individual group tutoring as well as drop-in advice sessions. Working in groups, students design and implement empirical research projects to effectively unpack how social problems impact upon individuals and the wider community, taking account of the role of the law in relation to the social problem. Since the first cohort of ICL students in 2008/09, students have identified and engaged with a wide range of social problems. ICL groups have 
researched on a broad range of topics, though specific topics routinely surface each academic year including access to housing; the status of refugees; the status of LGBTI individuals; and implications of the Small House Policy on Land Use and Rights in the New Territories. ${ }^{77}$

During the first semester, groups focus on drafting a research proposal which includes a detailed, critical review of secondary literature from which substantive research questions are identified and an appropriate research methodology designed. At the beginning of the course, delivery is weighted toward interactive lectures, where all groups are introduced to socio-legal analysis of social problems and to research ethics, which are particularly important given the human element involved in the design of such research projects including direct engagement with vulnerable individuals or groups. For example, student groups study the Stanley Milgram experiment to learn about the use of deception and its ethical implications ${ }^{78}$ as well as review different academic disciplines' ethics codes. ${ }^{79}$

\footnotetext{
${ }_{77}$ Under the Small House Policy, an indigenous male villager over the age of 18 can apply for a grant to build one small house in the New Territories http://www.landsd.gov.hk/en/legco/house.htm (Last Accessed 17 April 2015).

${ }^{78}$ See Milgram, S, 'Some Conditions of Obedience and Disobedience to Authority,' (1965) 18 Human Relations, 57.

${ }^{79}$ For example, the Socio-Legal Studies Association (SLSA) Code of Ethics is introduced to students as well as the American Anthropological Association's (AAA) Code of Ethics to consider the applicability of different discipline's ethical parameters and how these may apply to social research undertaken under the auspices of the ICL course.
} 
Formal screening of research proposals by the University Survey and Behavioural Research Ethics Committee may help to legitimise the research process and strengthen student's understanding of the role and importance of ethics in research. During the drafting of ethics applications, student groups receive substantial guidance and support from the course leader on research design and administrative colleagues provide additional research support by screening ethics applications. The application is primarily vetted at the faculty level before submission to the university level. Thus applications are reviewed and refined multiple times before submission to the university level.

Student groups are also introduced to both quantitative and qualitative research skills including questionnaire planning and design, interviewing social research subjects and focus group planning and facilitation. Though initially lectures are interactive, individual groups ordinarily break off to undertake group exercises and then relate generic case-based and research methods exercises to their own research topics. Alongside these modules on socio-legal analysis and social research methods, external speakers including NGO representatives, pro bono lawyers and academics are invited to give guest lectures on public interest lawyering. 
To illustrate, the Hong Kong Federation of Women's Centres (HKFWC), ${ }^{80}$ which runs a free legal advice clinic, is invited to introduce student groups to the situation and status of women in Hong Kong including issues such as disparity in economic earnings between men and women. Further, HKFWC help to facilitate the sharing of pro bono lawyers, peer counsellors and service users, which gives student groups' direct insight into the scope and nature of services provided by HKFWC's free legal advice clinic. The aim of these sessions is to draw the connection between public interest lawyering and the design and development of student groups' own empirical research projects.

With ethics approval confirmed, during semester two, student groups undertake fieldwork with research subjects. Student groups design research instruments including interview schedules and questionnaires, which are reviewed during individually tailored group tutoring. During the design process, the course leader offers detailed feedback on the phrasing and sequencing of interview and survey questions as well as any complications which may arise including the potential for bias in the design of questions or interviewer bias. Additionally, student groups are introduced to data analysis, particularly analysis of qualitative data using coding or framework analysis, which is informed by grounded theory. ${ }^{81}$ Given that it is difficult to teach generic social

\footnotetext{
${ }^{80}$ Hong Kong Federation of Women's Centres (HKFWC) see http://womencentre.org.hk/en (Last Accessed 26 March 2015).

${ }^{81}$ Framework analysis' roots are in Glaser \& Strauss' pivotal work, which suggested that theory should be grounded in the data generated through research (i.e. inductive research). Framework analysis allows for the identification of a priori themes (deductive research) as well as emergent themes (inductive research).
} 
research skills when each individual group is working on a highly specialized topic, over time the ICL course design has evolved ${ }^{82}$ to allow greater use of group tutoring individually tailored to the needs of each ICL group. Group tutoring is scheduled at key points in the research process including during the formation of research topics, submission of research ethics applications, design of research instruments and supervision during fieldwork.

The course includes both formative and summative assessment. In semester one student groups are required to give an oral research presentation in the latter part of the semester, which frames the social problem, identifies a research question and an appropriate research methodology to answer the question. Groups also submit a written research proposal, which includes a detailed literature review as well as a proposed research methodology, which may include quantitative or qualitative social research methods or a combination of both. In semester two, student groups are again required to give an oral research presentation to present preliminary empirical research findings from their fieldwork.

Importantly, during oral research presentations other peer groups are invited to ask questions and give written feedback directly to individual groups for their

\footnotetext{
${ }^{82}$ Several colleagues have been involved in the course design including the article author; Prof. Mike McConville; Dr. Arthur McInnis; former colleagues Prof. Marlene le Brun and Prof. Mark Hsiao. Each colleague has contributed their respective perspectives, skills and insight to the Course design, but the course has been inhibited by LLB programme constraints.
} 
consideration. This interactive process is designed to support student learning by encouraging student groups to identify any limitations in the research process including any potential for bias and how this may impact upon research findings. Individual groups are also required to undertake a self-evaluation of their group's research process in relation to each assessment. Including all groups in the evaluation process (while not informing the formal assessment process) helps to foster a sense of collegiality in the research process. At the end of the course student groups submit a final written report which includes an executive summary, a detailed literature review, research methodology, empirical research data analysis and findings as well as a conclusion. Though some groups present recommendations, this is not ultimately the goal of the ICL course, which instead aims to focus on unpacking the complexity of the social problem.

The design and implementation of the ICL course has not been without problems. The Faculty initially adopted the ICL as a compulsory ${ }^{83}$ course requirement on both the undergraduate (LLB) and postgraduate (JD) programmes. However, the structure and design of the course deviates substantially. On the LLB programme the course is offered across two semesters, allowing for substantial guidance and support during the research process. Conversely, on the JD programme the course was only offered in

\footnotetext{
${ }^{83}$ From 2015/16 the course is no longer compulsory on the JD programme and will be offered as an elective. The status of the ICL course on the LLB and whether it will continue as a compulsory course is currently being evaluated.
} 
summer semester, a substantially shorter term spanning seven weeks. This proved to be inherently problematic as student groups were required to design and implement research projects within a substantially shorter timeframe. Further, the course structure did not allow for the same level of guidance or support at all stages of the research process. ${ }^{84}$

At the undergraduate level, given the doctrinal bias of the undergraduate law curriculum, students often lack a solid grounding in socio-legal research at the point upon which they enter the course, which may hinder their understanding of the aims and objectives of the course as well as their socio-legal analysis of social problems. The recent adoption of foundational core courses on legal analysis and argumentation as well as jurisprudence and ethics in the Faculty of Law's LLB curriculum may allow greater scope to strengthen students understanding of alternative approaches to the study of law. Further, given the limited number of elective courses that law students can opt to take in the first and second year of the LLB degree, the majority of students lack a solid grounding in public interest law although courses such as administrative and constitutional law do expose students to strategic litigation cases and a limited

\footnotetext{
${ }^{84}$ The University requires that all students undertaking social research should be screened by the survey and behavioural research ethics review process. Given the seven week timeframe allocated to delivery of the ICL course on the JD programme, this formal review process is lacking and thus the legitimacy of the aims and objectives of the ICL course on the JD programme may be undermined. From 2015/16 the course is no longer compulsory and will be offered as an elective.
} 
number of individual law students also take clinical legal programmes such as the Refugee Rights Clinic alongside the ICL course.

Compared with doctrinal law courses, ICL is labour intensive ${ }^{85}$ for both students and the course leader, particularly during the second semester when student groups go out into the 'field' to interview civil society actors and policymakers. Greater flexibility is required to provide the tailored group tutoring, which individual student groups rely upon during the research process. On average, there are twelve ICL groups each year, the projects of which are distinct and consequentially require the design and implementation of different research methodologies. Thus the course leader has to be adaptable in order to respond to the individual research needs and challenges of each group.

As with other law courses, each semester students must complete a course teaching evaluation questionnaire to provide feedback on their learning experiences. However, this generic evaluation does not adequately capture how the ICL course impacts, if at all, on students' perceptions of the rule of law, access to justice and public interest law, key elements which underpin the philosophy of the ICL course's design. Thus, in 2014/15 a

\footnotetext{
${ }^{85}$ Socio-legal research and teaching is also susceptible to the doctrinal bias of the undergraduate curriculum. For socio-legal courses to be sustained effectively they require adequate support through recognition of the 'value' of the course including for example, the allocation of an appropriate number of course credits to account for the unique nature of the course and the significant time required to conduct empirical research. Students on the ICL course currently complain that the course is not given an adequate number of course credits. Additionally, the same numbers of contact hours are allocated to ICL as with other compulsory core courses, which follow the traditional model of two hours lecture per week and one-hour tutorial.
} 
pedagogical research project was initiated - Fostering Public Interested Lawyers: The

Individual, the Community and the Law. ${ }^{86}$ This empirical research project aims to learn

more about students' specific learning experiences on the ICL course including the influence that the course has had, if any, on LLB students and graduates' career aspirations and choices as well as perceptions of access to justice, the rule of law and public interest lawyering in Hong Kong.

While not directly inspired by any similar pedagogical evaluations of clinical legal programmes, insight was drawn from two large-scale surveys in the United States, after the JD. ${ }^{87}$ However, the research project differs substantially given that the aim of the survey is to evaluate the influence, if any, of a single socio-legal course as opposed to the entire JD or LLB programme's impact on career aspirations and choices. Further, given the focus of the ICL course on social problems, the research specifically intends to

\footnotetext{
${ }^{86}$ We aim to map and track the year of graduation to try to gauge the impact over time, if any, of the ICL course on LLB graduate's pursuant careers. The impact of the ICL course may not be immediate but in the longer term the course may influence perceptions of public interest law, including whether LLB Graduates participate in pro bono legal advice or other work in the public interest domain. An anonymous questionnaire was distributed to students entering the ICL course in September 2014. With limited exposure to the ICL course, following the introductory lectures, we wanted to survey students in relation to their perceptions of the nature of the ICL course in comparison to the broader learning experiences on the LLB, as well as gauge students' views on rule of law, access to justice and vulnerable groups in Hong Kong. This cohort of students will also be surveyed upon completion of the ICL course to map whether their initial expectations of the course were accurate and to try to evaluate if the course has influenced their views on rule of law and access to justice in Hong Kong.

87 'After the JD the first ten years' was a longitudinal study to learn more about the influence, if any, of the JD course on career aspirations and choices. See

http://www.americanbarfoundation.org/publications/afterthejd.html (Last Accessed 17 April 2015).
} 
evaluate whether the course influences LLB students and graduates' understanding of the connection between social problems, the individual, the community and the law.

At this stage it is too premature within our pedagogical research project to fully evaluate whether socio-legal education, and specifically the ICL course, can provide an effective means of fostering public interested lawyers as a way to strengthen equity and social justice in Hong Kong. However, from our initial survey results with students entering the ICL course ${ }^{88}$ the majority of students are aware that public interest law aims to help marginalized groups within society $(77 \%)$, though there is a lack of awareness amongst students as to the practicalities of public interest law including whether it is not-for-profit. $60 \%$ of students were uncertain as to whether public interest law is not-for-profit and $14 \%$ of students think it is carried out on a for-profit basis. The majority of students have undertaken legal internships $(88 \%)$, and many students have also undertaken community service programmes (49\%) with a relatively small percentage having undertaken overseas social service programmes (14\%). Only a minority of students have participated in any of the Law Faculty's public interest

\footnotetext{
${ }^{88}$ The questionnaire was sent to 119 students entering the ICL course. Our response rate is lower than expected at $36 \%$. There could be a number of factors for the response rate. Some students who gave further feedback on the ICL course expressed concern that they had only recently entered the course and therefore they did not have a clear understanding of the course's objectives at that stage. Additionally, relatively shortly after the questionnaire was circulated, the Hong Kong Students Federation called for a boycott of classes in response to the perceived failure to implement universal suffrage of the Chief Executive in Hong Kong in line with international standards. The boycott commenced on $22^{\text {nd }}$ September shortly after the questionnaire had been circulated. Attendance at lectures dropped as low as $45 \%$ and attendance at lectures only started to recover in the latter weeks of the course in late November 2014.
} 
programmes such as the Refugee Rights Clinic (9\%) or the Refugee Pro Bono Project (5\%). These findings suggest that only a limited number of LLB students voluntarily enter public interest law programmes.

While the pedagogical aims and objectives of the ICL course may differ substantially to clinical legal education programmes, the inclusion of empirical research with multiple stakeholders from legal, NGO and policy circles may effectively sensitize students to the cultural, social and political context in which law operates, and thus heighten students' awareness of the limitations of the law and lawyering. By exploring social problems experienced by vulnerable groups, students are exposed to different social strata within society. By engaging directly with stakeholders from civil society as well as policymakers and members of the vulnerable groups themselves, students can gain meaningful insight into the practical constraints of the law in providing an effective remedy to such vulnerable groups and the problems which they experience. Our ongoing pedagogical research aims to give an indication of the impact of ICL over time, if at all, on students' perceptions of the rule of law, access to justice and public interest law.

CONCLUSION

Though historically Hong Kong has prospered economically, a myriad of social problems persist which undermine equity and social justice in society. The 
development of public interest law in Hong Kong provides a pedagogical opportunity to cultivate socially responsible lawyers with the capacity to critically engage with and respond to social problems in society. Law schools within Hong Kong have increasingly adopted clinical legal education programmes as a means of fostering public interest lawyers. While pedagogically distinct, socio-legal courses such as ICL may complement efforts to foster public interest lawyers through allowing students to engage in empirical research with multiple stakeholders to unpack the context of law in which social problems are situated and consider the role of the individual, the community and the law's response. This article has demonstrated how pedagogically law schools can contribute meaningfully to the development of law students' sense of social responsibility. The 'impact' of socio-legal courses may be challenging to measure longitudinally, but potentially such courses allow for a seed of social awareness to be planted, which may bear fruit in the future. 